\title{
Sensory evaluation and nutritional value of cakes prepared with whole flaxseed flour
}

\author{
Avaliação sensorial e valor nutricional de bolos preparados com farinha integral de linhaça
}

Érica Aguiar MORAES ${ }^{1}$, Maria Inês de Souza DANTAS ${ }^{1}$, Dayane de Castro MORAIS ${ }^{1}$, Cassiano Oliveira da SILVA ${ }^{1}$,
Fátima Aparecida Ferreira de CASTRO ${ }^{1}$, Hércia Stampini Duarte MARTINO ${ }^{1}$, Sônia Machado Rocha RIBEIRO ${ }^{1 *}$

\begin{abstract}
The objective of this study was to evaluate the nutritional value, the oxidative stabilitiy, and consumer acceptance of cakes containing four different concentrations of flaxseed flour $(5,15,30$ and $45 \%)$ as partial replacement for wheat flour. The oxidative stability of polyunsaturated fatty acids was evaluated through the lipid peroxidation test (TBARS) in the flour and cakes. Linolenic acid was determined by gas chromatography as well as contents of protein, lipid, ash, and dietary fiber. Consumer acceptance was assessed using a structured hedonic scale of nine points. The oxidative stability of lipid flaxseeds was not affected by the heat treatment during flour processing and cake baking. Cakes made with 5, 15, and 30\% of flaxseed flour, the most accepted by consumers, had dietary fiber levels ranging from 3.5 to $6.2 \mathrm{~g}$ and linolenic acid ranging from 445 to $2,500 \mathrm{mg} .100 \mathrm{~g}^{-1}$ of the product. The cakes received claims of good and excellent source of dietary fiber and linolenic acid, respectively, both are bioactive compounds. The use of up to $30 \%$ of flaxseed flour in the preparation of cakes is a useful strategy to optimize the consumption of food rich in functional ingredients.
\end{abstract}

Keywords: flaxseed flour; cakes; lipid peroxidation; bioactive compounds; acceptance.

\section{Resumo}

O estudo teve por objetivos elaborar bolos contendo quatro diferentes níveis de farinha de linhaça (5, 15, 30 e 45\%) em substituição parcial da farinha de trigo, calcular o valor nutricional do produto e avaliar a aceitação. A estabilidade oxidativa dos ácidos graxos poli-insaturados foi avaliada por meio do teste da peroxidação de lipídios, na farinha e nos bolos. $\mathrm{O}$ ácido linolênico foi quantificado por cromatografia gasosa e foi determinada composição centesimal em proteína, lipídios, carboidratos, cinzas e fibras. A aceitação foi avaliada utilizando-se escala hedônica estruturada de nove pontos. A estabilidade oxidativa do lipídio da linhaça, avaliada pelo teste das substâncias reativas ao ácido tiobarbitúrico, não foi influenciada pelo tratamento térmico durante o processamento da farinha e durante o cozimento do bolo. Os bolos com 5, 15 e 30\% de farinha de linhaça, os mais aceitos pelos consumidores, apresentaram teores de fibra variando de 3,5 até 6,2 g e ácido linolênico variando de 445 até $2.500 \mathrm{mg} .100 \mathrm{~g}^{-1}$ de produto, constituindo boa e excelente fonte de ambos os compostos bioativos. A substituição de farinha de trigo por farinha de linhaça em até 30\%, no preparo de bolos, constitui uma estratégia útil para viabilizar o consumo de preparações ricas em ingredientes funcionais.

Palavras-chave: farinha de linhaça; bolo; peroxidação de lipídios; compostos bioativos; aceitação.

\section{Introduction}

Flaxseed (Linum usitatissimum) has been part of the human diet for thousands of years, and more recently it has been used as a source of nutraceuticals. It has been identified as a functional food, whose benefits to health are generally attributed to high concentrations of linolenic acids (omega-3) and lignins, as well as significant quantities of dietary fiber (CONFORTI; DAVIS, 2006; HUSSAIN et al., 2006; OOMAH; DER; GODFREY, 2006; TARPILA et al., 2002).

Flaxseed contains approximately $28 \%$ fiber, of which one third is soluble and has proved to reduce cholesterol and regulate blood glucose. The remaining two thirds of insoluble dietary fiber can increase fecal mass, reducing transit time in the lumen, preventing constipation and providing protection against colon cancer (HUSSAIN et al., 2006; CUNNANE et al., 1995).
Linolenic acid is the predominant fatty acid in the lipids of the flaxseed, and studies have showed its beneficial effect on the growth and development of children as well as on reducing the risk of cardiovascular disease, stroke, and inflammatory and immunological disorders (HUSSAIN et al., 2006; MARTIN et al., 2006; LUCAS et al., 2002).

Flaxseed is a food with higher contents of lignans, containing 75 to 800 times more of this substance than any other food (MOSCATTO; PRUDENCIO-FERREIRA; HAULY, 2004). Phytoestrogens, such as lignans, act on the estrogen metabolism and are purported to serve as an adjuvant in hormone replacement therapy and breast and prostate cancer prevention strategies (KNUST et al., 2006; THOMPSON et al., 2005; DEMARK-WAHNEFRIED et al., 2001).

Recebido para publicação em 23/10/2008

Aceito para publicação em 31/10/2009 (003875)

Departamento de Nutrição e Saúde CCB-II., Universidade Federal de Viçosa - UFV, Av. PH Rolfs, s/n, Campus Universitário, CEP 36570-000, Viçosa - MG, Brasil,

E-mail: sribeiro@ufv.br

${ }^{*}$ A quem a correspondência deve ser enviada 
Flaxseed consumption is still very low in Brazil despite the growing interest of specific consumer groups encouraged to adopt healthy eating habits. The growing consumer demand for food with nutritional and sensory quality as well as functional claim (MOSCATTO; PRUDENCIO-FERREIRA; HAULY, 2004) has called for research to develop new products, which include not only the nutritional and functional characterization, but also consider consumer acceptance. Bakery products such as cakes have high consumer acceptance and are important for delivering bioactive compounds into the human diet (ALPASLAN; HAYTA, 2006; VILLARROEL; PINO; HAZBÚN, 2006). Although cakes are not considered basic food, such as bread, they are accepted and consumed by people of different ages (BORGES et al., 2006). Among bakery products, they have become increasingly important in relation to consumption and market in Brazil (MOSCATTO; PRUDENCIO-FERREIRA; HAULY, 2004).

The objectives of this work were to prepare cakes with different proportions of flaxseed and wheat flours, to characterize their nutritional value, and to evaluate the cakes acceptance by consumers and lipid peroxidation of the flour and cakes.

\section{Materials and methods}

\subsection{Raw material}

Ingredients used in the preparation of cakes included: whole flaxseed flour, wheat flour, fresh eggs, refined sugar, chemical baking powder, vegetable oil, salt, and water. All ingredients, except for the whole flaxseed, were purchased from the local market. The flaxseed was supplied by a Brazilian industry.

\subsection{Preparation and selection of flaxseed flour}

Seeds of flax plants were dried using three different methods (Table 1). Following natural cooling to room temperature, the seeds were ground in a blender, sieved ( $850 \mu \mathrm{m}$ mesh) and the lipid peroxidation was evaluated. The flour with the lowest peroxidation rate was chosen as the selection criterion. Flour samples were taken, stored in plastic bags, and kept in a freezer at $-20^{\circ} \mathrm{C}$ for further chemical analyses.

\subsection{Lipid peroxidation in flour formulations}

\section{Extract preparation}

The total lipid extraction from the flour was carried out as described by Oomah, Mazza and Przybylski (1996). Lipids were extracted from $0.5 \mathrm{~g}$ flaxseed flour samples using $4 \mathrm{~mL}$ hexane and $20 \mu \mathrm{L}$ BHT $(0.01 \%)$. The mixture was homogenized in a shaker $(180 \mathrm{rpm})$ for 20 minutes and then centrifuged for 10 minutes. The supernatant was transferred into graduated

Table 1. Drying methods used for the production of flaxseed flour.

\begin{tabular}{clc}
\hline Treatment & Drying method & Binomial time $\times$ temperature \\
\hline F1 & Control & - \\
F2 & Conventional oven & 15 minutes, $120{ }^{\circ} \mathrm{C}$ \\
F3 & Conventional oven & 10 minutes, $150{ }^{\circ} \mathrm{C}$ \\
F4 & Microwave oven & 2 minutes, $70 \mathrm{~W}$ potency \\
\hline
\end{tabular}

tubes and the volume completed with hexane to $5 \mathrm{~mL}$. Part of the homogenized extract was used for the lipid peroxidation analysis, and the remaining hexane was evaporated under liquid nitrogen to determine the lipid concentration in the extract.

\section{Lipid peroxidationin the flour}

The lipid peroxidation in the flour was evaluated by the thiobarbituric acid-reactive substances (TBARS) assay according to Buege and Aust (1978). Extract aliquots (0.5 mL) were removed and transferred to tubes containing $2.0 \mathrm{~mL}$ TBARS reagent $[15 \%(\mathrm{w} / \mathrm{v})$ trichloracetic acid, $0.375 \%(\mathrm{w} / \mathrm{v})$ thiobarbituric acid, $0.25 \mathrm{M}$ hydrochloric acid]. The reaction mixture was kept in a hot water bath at $100{ }^{\circ} \mathrm{C}$ for 15 minutes, cooled, and centrifuged at $3.000 \mathrm{rpm}$ for 5 minutes.

Absorbance was measured at $535 \mathrm{~nm}$ using a spectrophotometer (Shimadzu UV-1601). Malondialdehyde (MDA) concentration was calculated using the molar absorptivity of $1.56 \times 10^{5} \mathrm{M}^{-1} \mathrm{~cm}^{-1}$ (BUEGE; AUSTE, 1978). The results were expressed in MDA nanomol per milligrams of lipid. The analyses were replicated three times in duplicate.

\subsection{Cake preparation}

The cakes were prepared immediately after the flour preparation, following a standard formulation, with the addition of four different levels of flaxseed flour. Table 2 shows the ingredients utilized in the cake preparation.

The ingredients egg yolk, sugar, and vegetable oil were homogenized with an electric mixer at medium speed for 5 minutes; next, wheat flour, whole flaxseed flour, salt, and water were added to the mixture. The mixture was homogenized until it was uniform in consistency, and the baking powder was added. The egg whites, beaten to a stiff froth at room temperature, were manually incorporated into the cake batter. The batter was placed into aluminum pans, previously oiled and sprinkled with wheat flour, and baked in a conventional oven pre-heated to $180^{\circ} \mathrm{C}$ for 25 minutes.

After cooling, the cakes were weighed and sliced in order to calculate the total cake yield and servings. The samples were taken, wrapped in plastic bags, and kept in a freezer at $-20{ }^{\circ} \mathrm{C}$ for further chemical analysis.

Table 2. Composition of cake formulation with four different proportions of wheat and flaxseed flours.

\begin{tabular}{lrrrr}
\hline \multirow{2}{*}{$\begin{array}{c}\text { Ingredients } \\
(\mathrm{g})^{1}\end{array}$} & \multicolumn{5}{c}{ B1 } & B2 & \multicolumn{1}{c}{ B3 } & B4 \\
\cline { 2 - 5 } & 270.7 & 242.2 & 199.5 & 156.7 \\
\hline Wheat flour & 14.2 & 42.7 & 85.5 & 128.2 \\
Flaxseed flour & 145.0 & 145.0 & 145.0 & 145.0 \\
Sugar & 30.0 & 30.0 & 30.0 & 30.0 \\
Baking powder & 60.0 & 60.0 & 60.0 & 60.0 \\
Oil & 150.0 & 150.0 & 150.0 & 150.0 \\
Egg & 60.0 & 60.0 & 60.0 & 60.0 \\
Water (mL) & \multicolumn{5}{c}{ (m) } \\
\hline${ }^{1}$ Quantity per recipe; ${ }^{2}$ Considering raw batter; B1 = formulation with 5\% flaxseed flour; \\
B2 = formulation with 15\% flaxseed flour; B3 = formulation with 30\% flaxseed flour; \\
B4 = formulation with 45\% flaxseed flour
\end{tabular}




\subsection{Yield factor}

The cake yield factor was calculated from the ratio cooked/ uncooked batter and the results expressed in number of servings of $80 \mathrm{~g}$ each.

\subsection{Chemical analyses}

\section{Lipid peroxidation in cakes}

The lipid peroxidation in cakes was evaluated according to Buege and Aust (1978), as described in Section 2.3, using $0.5 \mathrm{~g}$ cake samples, $4.0 \mathrm{~mL}$ hexane, and $20 \mu \mathrm{L}$ BHT for lipid fraction extraction.

\section{Chemical composition of cakes}

The determination of dry matter, protein, ether extract, and ash contents of cakes followed the methodology recommended by AOAC (ASSOCIATION..., 1997). The carbohydrate content was calculated from difference, using the equation: $100-$ (moisture + ether extract + ash + protein + fibers).

The content of Total Dietary Fiber (TDF) was determined by the enzymatic-gravimetric method recommended by AOAC (ASSOCIATION..., 2002). The caloric value was calculated using the following Atwater conversion factors: $9 \mathrm{kcal}^{\mathrm{g}} \mathrm{g}^{-1}$ of lipid, $4 \mathrm{kcal.g}{ }^{-1}$ of carbohydrate, and $4 \mathrm{kcal}^{-1} \mathrm{~g}^{-1}$ of protein (FRARY; JOHNSON, 2005).

\section{Linolenic acid content}

The linolenic acid content was determined by gas chromatography. The lipid fraction of cake samples $(0.1 \mathrm{~g})$ was obtained according to Folch, Lees and Stanley (1957). Next, saponification and esterification followed procedures described by Hartman and Lago (1973). The sample aliquots $(1.0 \mu \mathrm{L})$ containing methyl esters were injected (in duplicate) into a gas chromatograph with a Shimadzu AOC-17 autoinjector and a Shimadzu C-R7A integrator. The Carbowax capillary column $(30 \times 0.25 \mathrm{~mm})$ operated in the following temperature program: start $200{ }^{\circ} \mathrm{C}$, hold for 10 minutes, ramp $6^{\circ} \mathrm{C} /$ minutes to $240^{\circ} \mathrm{C}$, and hold for 16.6 minutes. The chromatographic conditions were as follows: the temperatures of the injector and detector were 240 and $260^{\circ} \mathrm{C}$ respectively and the split mode at 1:20 ratio. The carrier gas (nitrogen) flow was set to $0.5 \mathrm{~mL} /$ minute, $100 \mathrm{Kpa}$ pressure. An analytical curve of linolenic acid, ranging from 0 to $1000 \mathrm{ppm}\left(\mathrm{R}^{2}=0996\right)$ was used to quantify omega-3 fatty acids.

\subsection{Nutritional value of cakes as dietary fiber and linolenic acid source}

The nutritional value of servings of $80 \mathrm{~g}$ of the cakes as a source of fiber and linolenic acid was calculated, considering the average daily recommendation for adults of linolenic acid and dietary fiber as 1.3 and $25 \mathrm{~g} /$ day, respectively (INSTITUTE..., 2002). The four cake formulations were classified according to the categories proposed by Philippi (2008): food source (containing more than $5 \%$ of dietary recommended intakes -
DRI in a usual serving), good food source (contains between 10 and $20 \%$ of the DRI in a usual serving), and excellent food source (contains more than $20 \%$ of the DRI in a usual serving).

\subsection{Sensory analysis}

The assessment of acceptability of the four formulations of the flaxseed cake was carried out at local supermarkets, on the day the cakes were prepared. The samples, labeled with three digit numerals, were presented monadically to consumers following a complete randomized block design. Consumers evaluated the overall acceptance of formulations using a hedonic structured scale of 9 points. The data obtained from the acceptance test of the four flaxseed cake samples were used for the Internal Preference Mapping analysis.

\subsection{Statistical analysis}

The data from lipid peroxidation analyses of the flour and cakes were examined by ANOVA, and the mean contrasts were evaluated by the Tukey test, at $5 \%$ probability level. The results obtained from the acceptance test were evaluated using the internal preference mapping analysis. To carry out the Internal Preference Mapping or Multidimensional Preference Analysis (MDPREF), the acceptance data were organized in a matrix sampling design, sample (rows) and consumer (columns), that was subjected to the Principal Component Analysis (PCA) (CARNEIRO, 2001). The results were expressed as a sample dispersion plot generated by the first two principal components and another representing the PCA loads (correlation of the data from each customer's with the first two principal components) (DANTAS et al., 2004).

Statistical analyses were performed with Statistical Analysis System Software (SAS INSTITUTE, 1994).

\section{Results and discussion}

\subsection{Lipid peroxidation in flour formulations}

There were no significant differences for the lipid peroxidation among the flours prepared with seeds submitted to three different heat treatments. The average of malondialdehyde concentration ranged from 0,164 to $0,222 \mathrm{nmol} /$ of lipid. There was also no statistical difference between the lipid peroxidation in the control treatment (raw and crushed seed) and the lipid peroxidation in flours made from heat treated seeds. Therefore, heat treatment did not favor seeds lipid peroxidation.

The cakes were prepared with heat treated flour $\left(150^{\circ} \mathrm{C}\right.$; 10 minutes), which provided the most suitable physical characteristics for the handling of the product during ingredient homogenization.

\subsection{Cake yield}

The cake yield ranged from 7.4 to 8 servings of $80 \mathrm{~g}$ each, and the highest yield was provided by the formulation with $15 \%$ flaxseed flour (Table 3). 


\subsection{Lipid peroxidation in cakes}

The lipid peroxidation was not significantly different among the cakes made with 5, 15, and 30\% flaxseed flour (Table 4). The cake formulation with $45 \%$ flaxseed flour had significantly lower lipid peroxidation than that of the cakes prepared with lower concentrations. This was a surprising result since it was expected that the cakes containing higher levels of linolenic acid

Table 3. Yield of cakes made with four different concentrations of flaxseed flour.

\begin{tabular}{lcccc}
\hline & \multicolumn{4}{c}{ Formulation } \\
\cline { 2 - 5 } & B1 & B2 & B3 & B4 \\
\hline Raw batter & 680 & 715 & 705 & 715 \\
Baked cake & 595 & 640 & 635 & 629 \\
Yield factor & 1.14 & 1.11 & 1.11 & 1.13 \\
Servings* (number) & 7.4 & 8.0 & 7.93 & 7.86 \\
\hline
\end{tabular}

B1 = formulation with $5 \%$ flaxseed flour; B2 = formulation with $15 \%$ flaxseed flour; B3 $=$ formulation with $30 \%$ flaxseed flour; B4 = formulation with $45 \%$ flaxseed flour;

${ }^{*}$ Considering $80 \mathrm{~g}$ for each serving.

Table 4. Means and standard deviation of malondialdehyde concentration in cakes made with different concentrations of flaxseed flour.

\begin{tabular}{cc}
\hline Formulations & Malondialdehyde $\left(\mathrm{nmol.g} \mathrm{g}^{-1} \text { lipid }\right)^{\star}$ \\
\hline 5\% flaxseed flour & $26.78 \pm 6.81^{\mathrm{a}}$ \\
15\% flaxseed flour & $21.59 \pm 2.70^{\mathrm{a}}$ \\
30\% flaxseed flour & $21.60 \pm 3.41^{\mathrm{a}}$ \\
$45 \%$ flaxseed flour & $11.52 \pm 3.12^{\mathrm{b}}$ \\
\hline
\end{tabular}

${ }^{*}$ Mean and standard deviation of 8 repetitions, in duplicate; Means followed by different letters are significantly different by the Tukey test $(\mathrm{p}<0.05)$.

Table 5. Chemical composition of cakes made with four concentrations of flaxseed flour.

\begin{tabular}{lrrrr}
\hline \multicolumn{1}{c}{$\begin{array}{c}\text { Components } \\
\left(\mathrm{g} .100 \mathrm{~g}^{-1}\right)\end{array}$} & \multicolumn{4}{c}{ Formulations } \\
\cline { 2 - 5 } Moisture & 17.34 & 18.34 & 19.34 & \multicolumn{1}{c}{$\mathrm{B} 20.34$} \\
Dietary fiber & 3.55 & 5.10 & 6.92 & 8.13 \\
Ash & 2.59 & 2.48 & 2.60 & 2.82 \\
Lipids & 13.09 & 14.22 & 17.95 & 18.81 \\
Protein & 6.67 & 6.75 & 6.96 & 6.66 \\
Carbohydrate & 56.76 & 53.11 & 46.23 & 43.24 \\
Calories & 371.53 & 367.42 & 373.31 & 368.89 \\
Linolenic acid $(\mathrm{mg})$ & 445 & 1240 & 2500 & 3791
\end{tabular}

$\mathrm{B} 1=5 \%$ flaxseed flour; B2 = 15\% flaxseed flour; B3 = 30\% flaxseed flour; B $4=45 \%$ flaxseed flour. would present the highest lipid peroxidation. This result can be attributed to the protective effect of antioxidant compounds contained in the flaxseed. The antioxidant activity may have been optimized with the increase in the concentration of flaxseed in the formulation with $45 \%$ flour.

\subsection{Chemical composition and nutritional value of cakes}

The highest moisture content was found for the cake with $45 \%$ flaxseed flour, probably because the highest dietary fiber content can, through chemical interactions, retain water in the food matrix (Table 5). The components that showed more major quantitative variations were moisture, dietary fiber, and linolenic acid. Considering the supplying of dietary fiber and linolenic acid, one serving of flaxseed cake equivalent to $80 \mathrm{~g}$ can be considered an excellent source of both nutrients (Table 6).

\subsection{Sensory analysis}

A total of 110 consumers participated in the study including 42 men and 68 women, accounting for 38.2 and $61.8 \%$ respectively, between 16 and 82 years of ag. The internal preference mapping based on the acceptability data and carried out using PCA showed that the first two principal components accounted for,respectively, 41 and $35 \%$ of the total variation totalizing therefore, $76 \%$ of the total variance among the cake samples (Figure 1).

The spatial separation of the flaxseed cake samples suggests the existence of three groups of acceptance; one group formed by 15 and $30 \%$ of flaxseed cakes and the others formed by 5 and $45 \%$ of flaxseed cakes (Figure 1).

Figure 1 shows each point representing the correlations between the acceptance data of one or more consumers and the first two principal components. The correlation between consumers with at least one of the components indicates some difference in sample acceptance. The consumers were placed near the samples of their preference. Twenty-six percent of consumers preferred samples with 5, 15, and 30\% of flaxseed flour, confirming a positive correlation $(r \geq 0.5)$ with the first principal component. The second principal component also showed positive correlation $(\mathrm{r} \geq 0.5), 12 \%$ of the consumers preferred samples with 15 and 30\%, and negative correlation $(\mathrm{r} \geq-0.5), 15 \%$ of consumers preferred the sample with $45 \%$ of flaxseed flour.

Excellent acceptance by consumers (94\%) was observed for the formulation of flaxseed mousse in the work of Villarroel, Pino and Hazbún (2006). However, Hussain et al. (2006) found

Table 6. Nutritional value of a serving of $80 \mathrm{~g}$ and classification of cakes according the amount of fiber and linolenic acid provided to adults ${ }^{1}$.

\begin{tabular}{|c|c|c|c|c|c|c|}
\hline \multirow[t]{2}{*}{ Formulation } & \multicolumn{3}{|c|}{ Fiber DRI $=25 \mathrm{~g}$} & \multicolumn{3}{|c|}{ Linolenic acid $^{2} \mathrm{DRI}=1.3 \mathrm{mg}$} \\
\hline & g/serving & $\% \mathrm{DRI}$ & Classification & g/serving & $\%$ DRI & Classification \\
\hline B1 & 2.84 & 11.36 & Good source & 356.00 & 27.38 & Excellent source \\
\hline B3 & 5.54 & 22.16 & Excellent source & 2.000 & 153.85 & Excellent source \\
\hline B4 & 6.51 & 26.04 & Excellent source & 3.032 & 233.29 & Excellent source \\
\hline
\end{tabular}

${ }^{1}$ Considering DRI (dietary recommended intakes) average for adults of both sexes (INSTITUTE..., 2002). ${ }^{2}$ Based on AI (adequate intake). B1 = formulation with 5\% flaxseed flour; B2 $=$ Formulation with $15 \%$ flaxseed flour; B3 = formulation with $30 \%$ flaxseed flour; B4 = formulation with $45 \%$ flaxseed flour. 


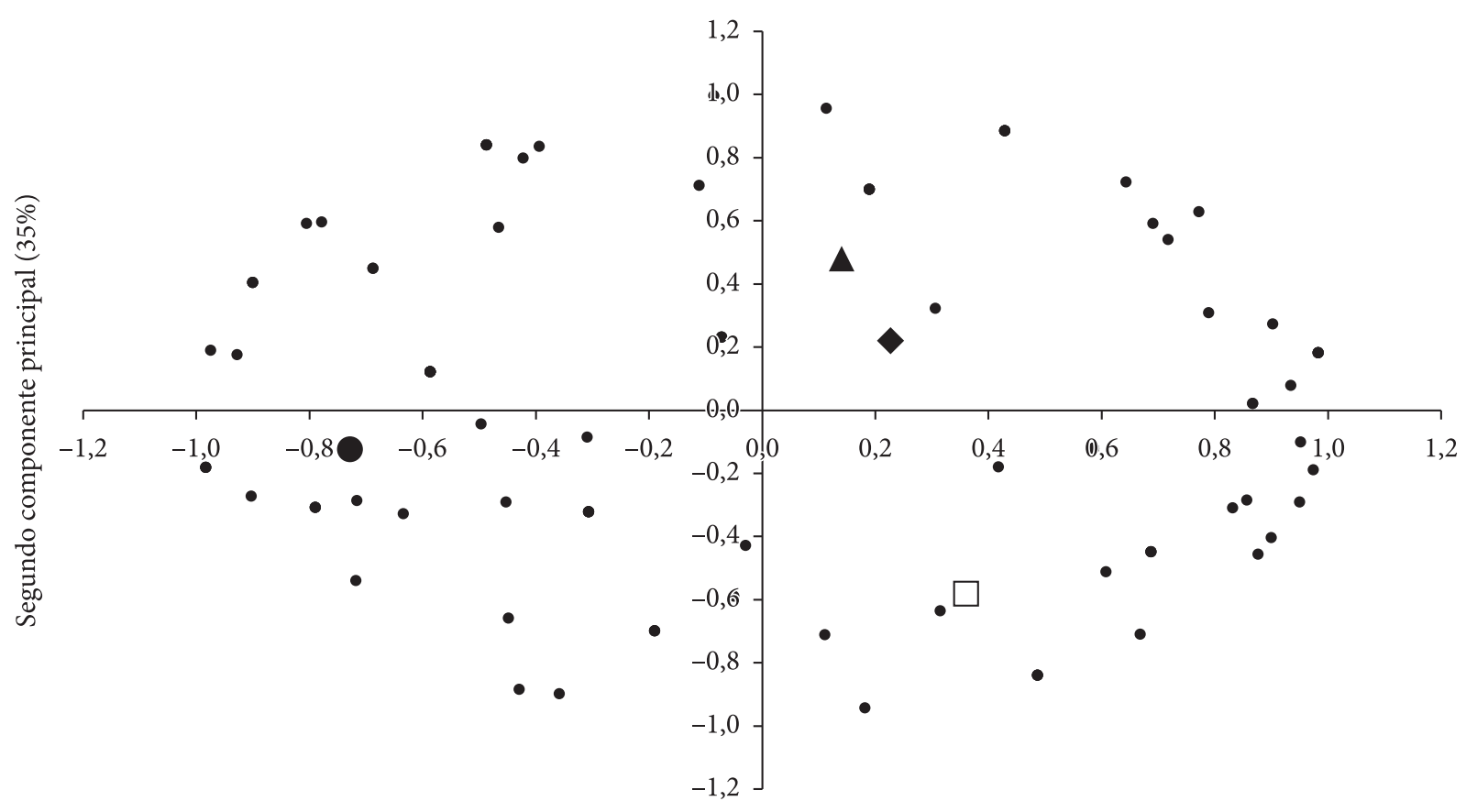

Primeiro componente principal (41\%)

$\square 5 \% \Delta 15 \% \bullet 30 \% \bullet 45 \%$

Figure 1. Dispersion of flaxseed cake samples in relation to consumer acceptance and correlations between acceptance data of each consumer and the first two principal components.

that biscuits supplemented with 25 and $30 \%$ of flaxseed flour were less accepted than those made only with wheat flour. The consumer acceptance of muffins added with flaxseeds, in the concentrations of 7.3, 11.6, and $15.5 \%$, was also significantly lower for all examined attributes, including appearance, color, flavor, texture, and acceptability, than that of the control muffins (RAMCHARITAR et al., 2005).

Alpaslan and Hayta (2006) evaluating bakery products suggested that corn, soybean, and flaxseed flours can be added to formulations in amounts up to $10 \%$. Cake formulations prepared with partial replacement of wheat flour for up to $30 \%$ of flaxseed flour were very well accepted.

\section{Conclusion}

The thermal treatment of flaxseeds aiming at flour production under the conditions used in this study did not affect lipid peroxidation.

The oven temperature $\left(180^{\circ} \mathrm{C}\right)$ used for baking the batter formulations did not cause significant degradation of linolenic acid in the cakes resulting in products with excellent source of omega-3 essential fatty acids.

The formulations made with up to $30 \%$ flaxseed flour as partial replacement of wheat flour had good acceptance, and the product presented nutritional and functional value classified as excellent source of dietary fiber and linolenic acid.
Adding flaxseed flour in bakery products is a useful strategy to increase the consumption of fiber and omega- 3 in the human diet. New formulations could therefore be tested aiming at the development and consumption of foods fortified with higher proportions of functional and nutritious ingredients.

\section{Acknowledgements}

The authors are grateful for the financial support provided by Fundação de Amparo à Pesquisa de Minas Gerais (FAPEMIG) and to Mr. Clóvis Schaefer for kindly supplying the linseed.

\section{References}

ALPASLAN, M.; HAYTA, M. The effect of flaxseed, soy and corn flours on the textural and sensory properties of a barkery product. Journal of Food Quality, v. 29, p. 617-627, 2006.

ASSOCIATION OF OFFICIAL ANALYTICAL CHEMISTS - AOAC. Official Methods of Analysis of the AOAC International. $17^{\text {th }} \mathrm{ed}$. Maryland, 1997.

ASSOCIATION OF OFFICIAL ANALYTICAL CHEMISTS - AOAC. Official Methods of Analysis of the AOAC. $16^{\text {th }} \mathrm{ed}$. Washington. D.C.: AOAC, 2002.

BORGES, J. T. S. et al. Utilização de farinha mista de aveia e trigo na elaboração de bolos. Boletim CEPPA, v. 24, n. 1, p. 145-162, 2006.

BUEGE, J. A.; AUSTE, S. D. Microsomal lipid peroxidation. In: FELISHER, S.; PACKER, L. (Ed.). Methods in enzymology. San Diego: Academic Press, 1978. v. 52 (Biomembranes, Part C). 
CARNEIRO, J. C. S. Processamento industrial de feijão, avaliação sensorial descritiva e mapa de preferência. 2001. 90 f. Dissertação (Mestrado)-Universidade Federal de Viçosa, Viçosa, 2001.

CONFORTI, F. D.; DAVIS, S. F. The effect of soya flour end flaxseed as a partial replacement for bread flour in yeast bread. International Journal of Food Science and Technology, v. 41, n. 2, p. 95-101, 2006.

CUNNANE, S. C. et al. Nutritional attributes of traditional flaxseed in healthy young adults. American of Journal of Clinical Nutrition, v. 8, p. 62-68, 1995.

DANTAS, M. I. S. et al. Mapa de preferência de couve minimamente processada. Horticultura Brasileira, v. 22, n. 1, p. 101-103, 2004.

DEMARK-WAHNEFRIED, W. et al. Pilot study of dietary fat restriction and supplementation in men with prostate cancer before surgery: exploring the effects on hormonal levels, prostate-specific antigen, and histopathologic features. Urology, v. 58, n. 1, p. 47-52, 2001.

FOLCH, L.; LEES, M.; SLAON-STANLEY, G. N. A simple method for the isolation and purification of total lipids from animal tissues. Journal of Biological and Chemistry, v. 226, p. 497-509, 1957.

FRARY, C. D.; JOHNSON, R. K. Energia. In: MAHAN, L. K.; ESCOTTSTUMP, S. Krause: alimentos, nutrição e dietoterapia. 11. ed. São Paulo: Rocca, 2005. p. 20-34.

HARTMAN, L.; LAGO, R. C. A. Rapid preparation of fatty acid methyl esters from lipids. Laboratory Practice, v. 22, n. 8, p. 175-176, 1973.

HUSSAIN, S. et al. Physical and sensoric attributes of flaxseed flour supplemented cookies. Turkish Journal of Biology, v. 30, p. 87-92, 2006.

INSTITUTE OF MEDICINE - IOM. Dietary reference intakes for energy, carbohydrate, fiber, fat, fatty acids, cholesterol, protein, and amino acids. Part 1. Washington, D.C.: National Academy Press, 2002. p. 9-32.

KNUST, U. et al. Contribution of linseed to urine and serum enterolignan levels in German females: a randomised controlled intervention trial. Food and Chemical Toxicology, v. 44, p. 1057-1064, 2006.
LUCAS, E. A. et al. Flaxseed improves lipid profile without altering biomarkers of bone metabolism in postmenopausal women. The Journal of Clinical Endocrinology and Metabolism, v. 87, n. 4, p. 1527-1532, 2002.

MARTIN, C. A. et al. Ácidos graxos poliinsaturados ômega-3 e ômega-6: importância e ocorrência nos alimentos. Revista de Nutrição, v. 19, n. 6, 2006.

MOSCATTO, J. A.; PRUDENCIO-FERREIRA, S. H.; HAULY, M. C. O. Farinha de yacon e inulina como ingredientes na formulação de bolo de chocolate. Ciência e Tecnologia de Alimentos, v. 24, n. 4, p. 634-640, 2004.

OOMAH, B. D.; DER, T. J.; GODFREY, D. V. Thermal characteristics of flaxseed (Linum usitatissimum) proteins. Food Chemistry, v. 98, p. 733-741, 2006.

OOMAH, B. D.; MAZZA, G.; PRZYBYLSKI, R. Comparison of flaxseed meal lipids extracted with different solvents. Lebensm.-Wiss.u.Techonologie, v. 29, p. 654-658, 1996.

PHILIPPI, S. T. Pirâmide dos alimentos: fundamentos básicos da nutrição. Barueri, SP: Manole, 2008. 378 p.

RAMCHARITAR, A. et al. Consumer acceptability of muffins with flaxseed (Linun usitatissimun). Journal of Food Science, v. 70, n. 7, p. 504-507, 2005.

SAS INSTITUTE INC. SAS/STAT User' Guide. $4^{\text {th }}$ ed. v. 2 . Version 6. Cary, NC: SAS Institute Inc, 1994. 846 p.

TARPILA, S. et al. The effect of flaxseed supplementation in processed foods on serum fatty acids and enterolactone. European Journal of Clinical Nutrition, v. 65, p. 157-165, 2002.

THOMPSON, L. U. et al. Dietary flaxseed alters biological markers in postmenopausal breast cancer. Clinical Cancer Research, v. 11, p. 3828-3835, 2005.

VILlARROEL, M.; PINO, L.; HAZBÚN, J. Desarrollo de una formulación optimizada de mousse de linaza (Linum usitatissimum). Archivos Latinoamericanos de Nutrición, v. 56, n. 2, 2006. 